\title{
Water relations composition among Egyptian cotton genotypes under water deficit
}

\author{
Maamoun A. Abdel-Moneam ${ }^{1}$ - Waleed A. E. Abido ${ }^{1 *}$ - Mohammed H. Ghoneima ${ }^{1}$ - Ágnes Hadházy ${ }^{2}$ \\ László Zsombik ${ }^{2}$ - Yaser M. El-Mansy ${ }^{3}$ - Mohab W. El-Shazly ${ }^{3}$ \\ ${ }^{1}$ Agronomy Department, Faculty of Agriculture, Mansoura University, Egypt \\ ${ }^{2}$ Research Institute of Nyiregyhaza, Institutes for Agricultural Research and Educational Farm, University of Debrecen, Hungary \\ ${ }^{3}$ Cotton Research Institute, Agricultural Research Center, Egypt \\ *Correspondence: madawy78@mans.edu.eg
}

\begin{abstract}
SUMMARY
Background: water shortage is one of the major factor effects on growth characters and yield of most crops. Objective: this study was conducted to get to know the reactions of some Egyptian cotton genotypes to water deficit. Methods: The genetic materials used in this study included thirteen cotton genotypes belonging to Gossypium barbadense L., from the Cotton Research Institute (CRI), which was devoted to establishing the experimental materials for this investigation. Results: the ratio of GCA/SCA was less than unity for all studied indices, indicating predominance of non-additive gene action (dominance and epistasis), which is an important in exploitation of heterosis through hybrid breeding. Results: The data showed significant reduction in water relationship characters for all parental genotypes under stress conditions. The Egyptian variety Giza 68 gave high values for most water relationship characters. Data revealed that the greater the value of tolerance index is, the larger the yield reduction is under water deficit conditions and the higher the stress sensitivity is becoming. The parental genotypes Giza 96 showed the highest reduction in yield under water deficit conditions. At the same time, the cross combination Minufy $x$ Australy showed higher values of yield reduction followed by the combinations Giza 67 x Australy. Of the male parents, the Russian genotype 10229 recorded the best GCA values for most water relationship characters. At the same time, the female parents, the old Egyptian genotype Giza 67 recorded the best values and exhibited good general combined for most water relationship characters. The cross combinations Giza $86 x$ Pima S6, Giza 77 x Pima S6, Giza 94 x Dandra and Giza 96 x Australy showed significant desirable SCA effect for most characters. Conclusion: relative water content \%, osmotic pressure, chlorophyll and carotenoids content indicates better availability of water in the cell, which increases the photosynthetic rate. Also, the higher level of proline accumulation in the leaves which was recorded under deficit water suggests that the production of proline is probably a common response of plant under water deficit conditions.
\end{abstract}

Keywords: cotton, water relations, correlation coefficients, general combining ability, specific combining ability

\section{INTRODUCTION}

Water scarcity (shortage) is one of the major limiting factors for crop development and yield. The anticipated demand in additional water supplies for agricultural production will lead to increase water scarcity in near future. Thus, irrigated crop production such as cotton system needs a better management to increase water use efficiency. Breeding to improve drought tolerant genotypes requires to identification of physiological mechanisms and morphological characters conferring drought tolerance. In this regard, (Iqbal et al., 2011) detected significant differences among 80 cotton genotypes for indices of drought tolerance. However, (Kashif et al., 2012) noticed significant variation of water regimes with respect to some chemical and productivity characters. Also, (Amjid et al., 2016) stated that the cotton genotypes differed significantly for relative water content, excised water loss and cell membrane stability. It is interesting to note that, the cotton parents which showed high values of RWC\% in each condition exhibit high values in total water content, free water and bound water \%, also showed reduced values in LWD values as compared with the other parents. This due to oxidative injury at the cellular level under water stress has high lipid peroxidation, which decreased stabilities of cell membrane and led to loss more water from cell (Sanchez et al., 2002; Abdel-Kader et al., 2015b). The osmotic pressure is considered as one of the important mechanisms of water deficit tolerance of plant (Khan et al., 2015), which promotes the protection of the plant cell structures including membrane and chloroplasts. Plants adjust to water stress by lowering tissue osmotic potentials by the accumulation of inorganic ions and /or organic substance to permit the maintenance of cell turgor. Chlorophyll contents as chlorophyll A and B plays a vital role in photosynthetic process which ultimately increase crop growth and yield. The adverse effect of water deficit on chlorophyll content has previously been showed by (Pirzad et al., 2011; AbdelKader et al., 2015a; Kannan et al., 2017). However, (Hamayun et al., 2010) studied the effect of drought stress on chlorophyll and found that water stress had decreased chlorophyll A, B and total chlorophyll. Terminal of stress occurring during the productive phase, flowering and boll, is known to induce boll reduction and reduce on boll size and weight as well as boll 3 shedding (Zangi, 2010). Besides, there is a significant decrease in RWC\% under water deficit conditions was due to reduced absorption of water from the soil and inabilities to control water loss through the stomata (Rahman et al., 2008; Ananthi and Vijayaraghavan, 2012; Kumar et al., 2013; Hu et al., 2013). In addition, under water stress conditions, the genotypes showed significant decreased in metabolic factors, such as decreased in chlorophyll (A, B), carotenoids content and enhanced accumulation of proline (Din et al., 2011). Indirect selection for stress environment based on performance of irrigated 
conditions would be effective (Anwar et al., 2011). Thus, the pre-requisite for success requires determination of the extent of genotypic variation within genotypes for these traits and their relative contribution to economic yield. The impact of water deficit (availabilities at farm gate) and insufficient availability of water during the sowing period seems to be the main reason for lessar acreage cotton crop and reduction in cotton production. Therefore, breeding for drought tolerance cotton is an important task and objective. For effective breeding of tolerant water deficit cotton varieties good selection criteria is needed to identify the tolerant cotton genotypes.

\section{MATERIALS AND METHODS}

The present study was done in the Agronomy Department, Faculty of Agriculture, Mansoura University. The investigation was carried out at Sakha Agric. Res. Stat. Kafr EL-Sheikh, Agric. Res. Center, Egypt, during 2014 and 2015 growing seasons. Genetic materials and experimental procedure: The genetic materials used in this study included thirteen cotton genotypes belonging to Gossypium barbadense L., from the Cotton Research Institute (CRI), which devoted to establish the experimental materials for this investigation. Experimental design and laboratory procedures: The thirteen parents were crossed, in such away Line $x$ Tester $(9 x 4)$ mating design by using four parents as a Tester parents i.e. Dandra, Pima S6, Australy and 10229 and nine cotton genotypes as a Line parents i.e. Giza 45, Minufi, Giza 67, Giza 68, Giza 86, Giza 77, Giza 94, Giza 96 and Giza 69, in 2014 crop season to produce $36 \mathrm{~F} 1$ hybrid seeds, and the original parents were also selfed. In 2015 season the $36 \mathrm{~F} 1$ hybrids and their parents were grown in a randomized complete block design (RCBD) with three replicates under two irrigated conditions. The first one is the normal irrigated 7 irrigations during the growing season and the second is the stress condition, three irrigations only during the growing season. Each experimental plot consisted of one row, measuring five meters in length and $0.70 \mathrm{~m}$ in width, with plants spaced $30 \mathrm{~cm}$ within row. Two plants were left per hill at 4 thinning time. The obtained data were subjected to different statistical and biometrical techniques according to their mating system. A separate analysis of variance for each character at each environment was done (Pelc et al., 1997) to detect the significance of the observed differences. Further line $\mathrm{x}$ tester analysis as proposed by (Kempthorne, 1957) and adopted by (Singh and Chaudhary, 1977) was deviated to partitioning the genetic variance of the F1 top crosses due to lines, testers and their interactions, provide informations about general and specific combining abilities of the parents and crosses (Table 1). In addition, it also provides additional informations about the various types of gene effects.

Table 1. The form of the analysis of variance for line $\mathbf{x}$ tester analysis

\begin{tabular}{lccc}
\hline \multicolumn{1}{c}{ S.O.V } & Df & M.S & E.M.S \\
\hline Replication & $\mathrm{r}-1$ & $\mathrm{MS}_{\mathrm{r}}$ & $\sigma^{2} \mathrm{e}+\mathrm{r}^{2} \mathrm{~g}$ \\
Genotypes & $\mathrm{g}-1$ & $\mathrm{MS}_{\mathrm{g}}$ & $\sigma^{2} \mathrm{e}+\mathrm{r} \sigma^{2} \mathrm{p}$ \\
Parents & $\mathrm{p}-1$ & & $\sigma^{2} \mathrm{e}+\mathrm{r} \sigma^{2} \mathrm{e}$ \\
Crosses & $\mathrm{c}-1$ & & \\
Parents vs Crosses & 1 & & $\sigma^{2} \mathrm{e}+\mathrm{r}(($ Cov.F.s-2Cov.H.s $)+\mathrm{rt}($ Cov.H.s $))$ \\
Lines & $1-1$ & $\mathrm{M}_{1}$ & $\sigma^{2} \mathrm{e}+\mathrm{r}(($ Cov.F.s-2Cov.H.s $)+\mathrm{rl}($ Cov.H.s $))$ \\
Testers & $\mathrm{t}-1$ & $\mathrm{M}_{2}$ & $\sigma^{2} \mathrm{e}+\mathrm{r}(($ Cov.F.s-2Cov.H.s $)$ \\
Lines x Testers & $(1-1)(\mathrm{t}-1)$ & $\mathrm{M}_{3}$ & $\sigma^{2} \mathrm{e}$ \\
Error & $(\mathrm{r}-1)(\mathrm{g}-1)$ & $\mathrm{M}_{4}$ & \\
\hline
\end{tabular}

Where, $r, g, p, c$ are the number of replications, genotypes, parents and crosses respectively.; $\mathrm{L}=$ number of lines (female parents).; $\mathrm{t}=$ number of testers (male parents).; $\sigma^{2} \mathrm{e}=$ plot environmental variance.

\section{Genetic components}

According to (Kempthorne, 1957; Kearsey and Pooni, 1996) the variance of general and specific combining abilities for each experiment was computed from the covariance's of full and half sib families as follows:

$$
\begin{aligned}
& \text { Cov Hs (lines) }=\frac{\mathrm{M} 1-\mathrm{M} 3}{\mathrm{rt}} \text {; } \\
& \text { Cov Hs (testers } \left.)=\frac{\mathrm{M} 2-\mathrm{M} 3}{\mathrm{rl}} ; \text { Cov Hs (average }\right)=\frac{1}{\mathrm{r}(2 \mathrm{lt}-\mathrm{l}-\mathrm{t})}\left\{\frac{(\mathrm{l}-1)(\mathrm{Ml})+(\mathrm{t}-1)(\mathrm{Mt})}{\mathrm{l}+\mathrm{t}-2}-\mathrm{Mlt}\right\} \\
& \sigma^{2} \text { gca }=\operatorname{Cov} \mathrm{Hs}=\frac{(1+\mathrm{F})}{4}=\frac{1}{2} \sigma^{2} \mathrm{~A} ; \sigma^{2} \mathrm{sca}=\frac{\mathrm{M}_{\mathrm{lt}}-\mathrm{M}_{\mathrm{e}}}{\mathrm{r}}=\mathrm{Cov} \text { full sib.; } \sigma^{2} \mathrm{D}=\mathrm{Cov} \text { full sib }-2 \operatorname{Cov} \text { Hs.; } \sigma^{2} \mathrm{sca}= \\
& \left(\frac{1+\mathrm{F}}{2}\right)^{2}=\sigma^{2} \mathrm{D} \\
& \sigma^{2} \mathrm{D}=\sigma^{2} \mathrm{sca}
\end{aligned}
$$


where, $\mathrm{Cov} \mathrm{Hs}=$ is the covariance half sibs.; Cov Fs = is the covariance full sibs.; $\sigma^{2}$ gca, $\sigma^{2}$ sca $=$ are the variance of general and specific combining ability.; $\sigma^{2} \mathrm{~A}, \sigma^{2} \mathrm{D}=$ are the component of genetic variance due to additive and dominance variances.; $\mathrm{F}=$ is the coefficient of inbreeding which was considered equal one.; $\sigma^{2} \mathrm{G}=\sigma^{2} \mathrm{~A}+\sigma^{2} \mathrm{D}$

\section{Estimates of heterosis}

The values of heterosis were determined as the percentage deviation from the $\mathrm{F}_{1} \mathrm{~s}$ hybrids over the better parents (B.P.) as follow:

$$
\mathrm{H}(\text { B.P. })=\frac{\overline{\mathrm{F} 1}-\overline{\mathrm{B} . \mathrm{P}}}{\overline{\mathrm{B} . \mathrm{P}}} X 100 \text {. }
$$

The significance of heterosis was tested using the least significant differences value (L.S.D) at $0.5 \%$ level of probabilities according to the formula of (Steel et al., 1997)

$$
\text { L.S.D at }{ }_{0.05}=\mathrm{t}_{0.05} \mathrm{x} \mathrm{s} \overline{\mathrm{d}}, \mathrm{s} \overline{\mathrm{d}}=\sqrt{\frac{2 M s_{e}}{r}}
$$

\section{General and specific combining abilities effects a. General combining abilities:}

$$
\begin{aligned}
& \text { Lines } g_{1}=\frac{x_{1 . .}}{\operatorname{tr}}-\frac{x . .}{l t r} \\
& \text { Testers } g_{j}=\frac{x_{j} \ldots}{\operatorname{lr}}-\frac{x_{\ldots} .}{l t r}
\end{aligned}
$$

Where, $\mathrm{g}_{1}=$ is the general combining ability effect.; $X_{\mathrm{i} . .}$ $=$ is the total value of crosses in which the line involved over replications.; $\mathrm{X}_{\mathrm{j} . . .}=$ is the total value of crosses in which the tester involved over replications.; $X_{\ldots}=$ is the general total for crosses; $\mathrm{R}, 1, \mathrm{t}=$ are the number of replications, line and testers respectively.

\section{b. Specific combining ability:}

$$
S_{i j}=\frac{x_{i j . .}}{r}-\frac{x_{i . .}}{\operatorname{tr}}-\frac{x_{j . .}}{\operatorname{lr}}-\frac{x . .}{1 t r}
$$

Where, $S_{i j}=$ is the specific combining ability effects; $\mathrm{X}_{\mathrm{ij}}=$ is the total value of crosses between lines and testers over replications.

\section{RESULTS AND DISCUSSION}

Analysis of variance for water relations leaves chemical composition and drought tolerance indices are shown in Tables 2 and 3. The data revealed significant differences among the genotypes for all studied characters, indicating the presence of considerable amount of genetic variabilities among the evaluated genotypes. Such variation could be attributed to the varied genetic background. Further partitioning of genotypes means squares to their components exhibited that parents mean squares were significant for all studied characters under stress and normal conditions, showing sufficient variabilities among the parents which can generate potential and promising hybrids.

The variance due to males and females were also significant for most studied characters and majority than the variance due to interactions (lines $\mathrm{x}$ testers), these results indicated that the experimental materials possessed considerable variabilities and the two types of combining abilities were involved in the genetic expression of these characters. The testers contributed a major share to the genetic variance in respect to most physiological and chemical characters under stress and

\begin{tabular}{|c|c|c|c|c|c|c|c|c|c|c|c|}
\hline \multirow[t]{2}{*}{ S.O.V } & \multirow[t]{2}{*}{ Df } & \multicolumn{2}{|c|}{$\begin{array}{c}\text { Total water content } \\
(\%)\end{array}$} & \multicolumn{2}{|c|}{$\begin{array}{c}\text { Free water } \\
(\%)\end{array}$} & \multicolumn{2}{|c|}{$\begin{array}{c}\text { Bound water } \\
(\%)\end{array}$} & \multicolumn{2}{|c|}{$\begin{array}{c}\text { Leaf water deficit } \\
(\%)\end{array}$} & \multicolumn{2}{|c|}{$\begin{array}{c}\text { Relative water content } \\
(\%)\end{array}$} \\
\hline & & $\mathbf{N}$ & $\mathbf{S}$ & $\mathbf{N}$ & $\mathbf{S}$ & $\mathbf{N}$ & $\mathbf{S}$ & $\mathbf{N}$ & $\mathbf{S}$ & $\mathbf{N}$ & $\mathbf{S}$ \\
\hline Replication & 2 & 0.14 & 0.12 & 0.05 & 0.01 & 0.36 & 0.06 & 0.01 & 0.14 & $17.52 * *$ & $7.70 * *$ \\
\hline Genotypes & 48 & $67.50 * *$ & $21.96 * *$ & $2.34 * *$ & $0.48^{* *}$ & $45.85^{* *}$ & $17.45^{* *}$ & $3.52 * *$ & $5.62 * *$ & $74.86^{* *}$ & $14.31 * *$ \\
\hline Parents & 12 & $4.28 * *$ & $3.10^{* * *}$ & $0.49 * *$ & $0.21^{* *}$ & $1.99 * *$ & $2.38 * *$ & $2.81 * *$ & $1.90 * *$ & $4.78^{* *}$ & $2.99 * *$ \\
\hline Crosses & 35 & $27.15^{* *}$ & $14.08 * *$ & $1.03 * *$ & $0.52^{* *}$ & $18.92 * *$ & $9.94 * *$ & $1.76^{* *}$ & $1.69 * *$ & $30.73 * *$ & $12.16^{* *}$ \\
\hline $\begin{array}{l}\text { Parents } \\
\text { Crosses }\end{array}$ & 1 & 2238.3 & $523.6^{* *}$ & $70.38 * *$ & $2.01 * *$ & $1514.9 * *$ & $460.99 * *$ & $73.77 * *$ & $187.70 * *$ & $2460.4 * *$ & $225.50 * *$ \\
\hline Lines & 8 & $24.99 * *$ & $10.95 * *$ & $1.06 * *$ & $0.50 * *$ & $16.75^{* *}$ & $7.28 * *$ & $2.27 * *$ & $1.26 * *$ & $26.35^{* *}$ & $8.93 * *$ \\
\hline Testers & 3 & $112.71 * *$ & $21.87 * *$ & $1.49 * *$ & $0.32^{* *} *$ & $89.58 * *$ & $17.01 * *$ & $2.56 * *$ & $2.80 * *$ & $79.07 * *$ & $16.96 * *$ \\
\hline Lines x Testers & 24 & $17.17 * *$ & $14.16^{* *}$ & $0.96 * *$ & $0.56^{* *}$ & $10.80 * *$ & $9.94 * *$ & $1.49 * *$ & $1.69 * *$ & $26.14 * *$ & $12.64 * *$ \\
\hline Error & 96 & 1.15 & 0.85 & 0.05 & 0.02 & 0.88 & 0.68 & 0.10 & 0.11 & 2.36 & 1.20 \\
\hline$\sigma^{2} \mathrm{GCA}$ & & 0.18 & -0.001 & 0.001 & -0.001 & 0.15 & -0.0001 & 0.01 & -0.0001 & 0.1 & -0.01 \\
\hline$\sigma^{2} \mathrm{SCA}$ & & 5.29 & 4.46 & 0.30 & 0.18 & 3.29 & 3.12 & 0.47 & 0.53 & 7.68 & 3.76 \\
\hline$\sigma^{2} \mathrm{GCA} / \sigma^{2} \mathrm{SCA}$ & & 0.03 & -0.0002 & 0.003 & -0.006 & 0.05 & 0.00 & 0.02 & -0.0002 & 0.01 & -0.003 \\
\hline $\mathrm{CV} \%$ & & 1.27 & 1.33 & 1.91 & 1.62 & 1.28 & 1.37 & 3.54 & 3.31 & 2.02 & 1.81 \\
\hline
\end{tabular}
non-stress conditions. In this regard, (Iqbal et al., 2011; Kashif et al., 2012; Amjid et al., 2016).

Table 2. Analysis of variance for line $\mathbf{x}$ tester and combining ability for water relations and leaves chemical composition under normal and water stress conditions 
Table 2. continued

\begin{tabular}{|c|c|c|c|c|c|c|c|c|c|c|c|}
\hline \multirow[t]{2}{*}{ S.O.V } & \multirow[t]{2}{*}{ Df } & \multicolumn{2}{|c|}{$\begin{array}{c}\text { Osmotic pressure } \\
\text { (bar) }\end{array}$} & \multicolumn{2}{|c|}{$\begin{array}{l}\text { Chlorophyll A } \\
\left(\mathrm{mg} \mathrm{g}^{-1} \mathbf{d w t}\right)\end{array}$} & \multicolumn{2}{|c|}{$\begin{array}{l}\text { Chlorophyll B } \\
\text { (mg g-1 dwt) }\end{array}$} & \multicolumn{2}{|c|}{$\begin{array}{l}\text { Carotenoides } \\
\left(\mathrm{mg} \mathrm{g}^{-1} \mathrm{dwt}\right)\end{array}$} & \multicolumn{2}{|c|}{$\begin{array}{c}\text { Proline } \\
\left(\mathbf{m g ~ g}^{-1} \text { fwt }\right)\end{array}$} \\
\hline & & $\mathbf{N}$ & $\mathbf{S}$ & $\mathbf{N}$ & $\mathbf{S}$ & $\mathbf{N}$ & $\mathbf{S}$ & $\mathbf{N}$ & $\mathbf{S}$ & $\mathbf{N}$ & $\mathbf{S}$ \\
\hline Replication & 2 & 0.003 & 0.02 & 0.01 & 0.001 & 0.001 & 0.0001 & 0.003 & 0.001 & 9.47 & 188.30 \\
\hline Genotypes & 48 & $1.47 * *$ & $1.46^{* *}$ & $0.29 * *$ & $0.10 * *$ & $0.02 * *$ & $0.01 * *$ & $0.04 * *$ & $0.02 * *$ & $5014.6 * *$ & $12172.9 * *$ \\
\hline Parents & 12 & $0.73 * *$ & $0.60 * *$ & $0.10 * *$ & $0.01 *$ & $0.01 * *$ & $0.01 * *$ & $0.01 * *$ & $0.003 * *$ & $201.58 * *$ & 108.66 \\
\hline Crosses & 35 & $0.30 * *$ & $0.42^{* *}$ & $0.16^{* *}$ & $0.12 * *$ & $0.02^{* *} *$ & $0.02 * *$ & $0.03 * *$ & $0.018^{* *}$ & $4725.39 * *$ & $4713.9^{* *}$ \\
\hline Parents vs Crosses & 1 & $51.35 * *$ & $48.15^{* *}$ & $7.02 * *$ & $0.36^{* *}$ & $0.33^{* *}$ & $0.079 * *$ & $1.05 * *$ & $0.23 * *$ & $72891.88 * *$ & $418009.02 * *$ \\
\hline Lines & 8 & $0.38^{* *}$ & $0.31 * *$ & $0.16^{* *}$ & $0.12 * *$ & $0.02 * *$ & $0.02 * *$ & $0.03 * *$ & $0.02 * *$ & $6050.74 * *$ & $3523.62 * *$ \\
\hline Testers & 3 & $0.45^{* *}$ & $0.70 * *$ & $0.13 * *$ & $0.09 * *$ & $0.02 * *$ & $0.003 * *$ & $0.02 * *$ & $0.03 * *$ & $6815.01 * *$ & $7810.29 * *$ \\
\hline Lines $\mathrm{x}$ Testers & 24 & $0.25^{* *}$ & $0.42 * *$ & $0.17 * *$ & $0.12 * *$ & $0.02 * *$ & $0.02 * *$ & $0.02 * *$ & $0.02 * *$ & $4022.40 * *$ & $4723.55^{* *}$ \\
\hline Error & 96 & 0.013 & 0.024 & 0.007 & 0.004 & 0.001 & 0.0004 & 0.001 & 0.001 & 189.40 & 229.02 \\
\hline$\sigma^{2} \mathrm{GCA}$ & & 0.001 & -0.00 & -0.0001 & 0.0001 & -0.00 & -0.00 & 0.00 & 0.00 & 12.64 & -0.17 \\
\hline$\sigma^{2} \mathrm{SCA}$ & & 0.08 & 0.13 & 0.05 & 0.04 & 0.01 & 0.01 & 0.01 & 0.01 & 1257.21 & 1474.68 \\
\hline$\sigma^{2} \mathrm{GCA} / \sigma^{2} \mathrm{SCA}$ & & 0.01 & 0.00 & -0.002 & 0.003 & 0.00 & 0.00 & 0.00 & 0.00 & 0.0101 & -0.0001 \\
\hline $\mathrm{CV} \%$ & & 2.96 & 3.13 & 2.25 & 2.08 & 1.77 & 1.56 & 2.32 & 2.22 & 4.37 & 2.56 \\
\hline
\end{tabular}

*, ** Significant at 0.05 and 0.01 probability levels, respectively, $\mathrm{N}=$ normal irrigation and $\mathrm{S}=$ water stress

Table 3. Analysis of variance of the studied cotton genotypes for drought tolerance indices under normal and water stress conditions

\begin{tabular}{lccccccccccc}
\hline \multicolumn{1}{c}{ S.O.V } & Df & Tol & M.P. & H.M. & S.S.I. & G.M.P. & S.T.I. & Y.I. & Y.S.I & R.D.I & D.I. \\
\hline Replication & 2 & 38.76 & 17.30 & 10.87 & 0.05 & 13.58 & 0.003 & 0.003 & 0.003 & 0.01 & 0.01 \\
Genotypes & 48 & $309.65^{* *}$ & $376.38^{* *}$ & $391.45^{* *}$ & $0.55^{* *}$ & $381.21^{*}$ & $0.03^{* *}$ & $0.10^{* *}$ & $0.03^{* *}$ & $0.05^{* *}$ & $0.12^{* *}$ \\
Parents & 12 & $367.24^{* *}$ & $418.59^{* *}$ & $482.05^{* *}$ & $0.93^{* *}$ & $446.41^{*}$ & $0.05^{* *}$ & $0.13^{* *}$ & $0.05^{* *}$ & $0.09^{* *}$ & $0.17^{* *}$ \\
Crosses & 35 & $293.22^{* *}$ & $299.66^{* *}$ & $298.22^{* *}$ & $0.43^{* *}$ & $296.44^{* *}$ & $0.02^{* *}$ & $0.07^{* *}$ & $0.02^{* *}$ & $0.04^{* *}$ & $0.10^{* *}$ \\
Parents vs Crosses & 1 & $193.62^{* *}$ & $2554.96^{* *}$ & $2567.36^{* *}$ & 0.06 & $2565.43^{*}$ & 0.003 & $0.44^{* *}$ & 0.003 & 0.01 & $0.22^{* *}$ \\
Lines & 8 & $558.07^{* *}$ & $168.81^{* *}$ & $150.72^{* *}$ & $0.81^{* *}$ & $155.63^{* *}$ & $0.04^{* *}$ & $0.04^{* *}$ & $0.04^{* *}$ & $0.07^{* *}$ & $0.11^{* *}$ \\
Testers & 3 & $175.06^{* *}$ & $490.64^{* *}$ & $586.95^{* *}$ & $0.49^{* *}$ & $537.90^{* *}$ & $0.03^{* *}$ & $0.17^{* *}$ & $0.03^{* *}$ & $0.05^{* *}$ & $0.20^{* *}$ \\
Lines x Testers & 24 & $219.70^{* *}$ & $319.40^{* *}$ & $311.29 * *$ & $0.30^{* *}$ & $313.20^{* *}$ & $0.02^{* *}$ & $0.07 * *$ & $0.02^{* *}$ & $0.03^{* *}$ & $0.08^{* *}$ \\
Error & 96 & 34.28 & 44.70 & 42.84 & 0.05 & 43.46 & 0.003 & 0.009 & 0.003 & 0.01 & 0.01 \\
$\sigma^{2}$ GCA & & 1.32 & -0.36 & -0.24 & 0.002 & -0.30 & 0.0001 & 0.00 & 0.0001 & 0.0002 & 0.0003 \\
$\sigma^{2}$ SCA & & 60.11 & 93.31 & 91.27 & 0.08 & 91.69 & 0.004 & 0.02 & 0.004 & 0.01 & 0.02 \\
$\sigma^{2}$ GCA $/ \sigma^{2}$ SCA & & 0.02 & -0.004 & -0.003 & 0.03 & -0.003 & 0.03 & 0.00 & 0.03 & 0.02 & 0.02 \\
CV $\%$ & & 26.69 & 8.99 & 9.05 & 20.68 & 8.99 & 7.05 & 9.90 & 7.05 & 7.04 & 14.15 \\
\hline
\end{tabular}

*, ** Significant at 0.05 and 0.01 probability levels, respectively, $\mathrm{N}=$ normal irrigation and $\mathrm{S}=$ water stress

Drought indices which provide a measure of drought based on loss of yield under drought conditions in compares to normal conditions. The analysis of variance (Table 3) showed highly significant for all drought tolerance indices, which indicated that genotypes were differing for genes controlling such characters. Significant differences were detected among parents, hybrids and parent's vs hybrids for most indices, indicating the existence of variabilities among parents and transmitted to cross combinations. Estimates of variances due to general and specific combining abilities for indices under study are presented in Table 3. General combining ability for female parents, testers, were highly significant for all studied indices and large in magnitude than male parents. However, SCA variances which due to interactions of line $\mathrm{x}$ testers were also high significant for all studied indices. The ratio of GCA/SCA was less than unity for all studied indices, indicating predominance of non-additive gene action (dominance and epistasis), which is an important in exploitation of heterosis through hybrid breeding. Hence, substantial improvement in these indices may be achieved through recurrent selection followed by selection under stress conditions. The SCA variances were greater than GCA for all studied characters under stress and non-stress conditions, indicating more important role of nonadditive type of gene effect.

The proportional contributions of lines (females) and testers (males) and their interactions to the total variance for different characters are presented in Tables 4 and 5. The data revealed that the maximum contribution of the total variance for most studied characters in both normal and stress conditions were made by lines $\mathrm{x}$ testers (male $\mathrm{x}$ female interaction). At the same time, the 7 contribution due to line parents were greater than contribution due to testers in the stress condition. The physiological parameters such as relative leaf water content (RWC), leaf water deficit (LWD), osmotic pressure (OPCS), chlorophyll A, chlorophyll B, carotenoids and leaf proline accumulation are some sensitive physiological and biochemical indicator used to study the response of cotton plants under stress condition. The data presented 
in Table 6 show significant reduction in water relationship characters for all parental genotypes under stress condition. The highest RWC\% was observed by the parents Giza 77 followed by Giza 86 and Giza 67 under normal and stress conditions. On the other side, the Egyptian extra-long staple variety Minufy and Giza 96 showed the lowest values for RWC\% under normal and stress conditions. The Egyptian variety Dandra showed decreased in RWC\% and LWD\%. The Egyptian variety Giza 68 (as a common parent for most extra-long varieties) gave high values for most water relationship characters. The observed significant decrease in RWC\% under water deficit conditions was due to reduced absorption of water from the soil and inabilities to control water loss through the stomata. Similar results were obtained by (Ananthi and Vijayaraghavan, 2012; Kumar et al., 2012, Hu et al., 2013). It is interesting to note that, the cotton parents which showed high values of RWC\% in each condition exhibit high values in total water content, free water and bound water $\%$, also showed reduced values in LWD values as compared with the other parents. This due to oxidative injury at the cellular level under water stress has high lipid peroxidation, which decreased stabilities of cell membrane and led to loss more water from cell (Abdel-Kader et al., 2015b). The highest RWC\% was recorded by the cross combinations Giza 77 x Pima S6 followed by Giza 86 x Dandra, Giza 86 x 10229 and Giza 99 x Dandra under well irrigated and deficit conditions. These combinations surpassed all crosses in water relation characters under stress and normal conditions. Genotypic variation of leaf water relation may be attributed to the differences in abilities to absorption more water from the soil and the abilities to reduce water loss through stomata. It may be also due to differences in abilities of genotypes to maintain tissue tiger and hence physiological activities (Khan et al., 2015). Data illustrated in Table 6 revealed that all 13 cotton parents exhibited some degree of osmotic adjustment in response to water deficit. The parents Giza 77, Giza 68 and Giza 67 showed the lowering values of osmotic pressure in cell tissue under normal and deficit conditions. However, the parents Dandra, Giza 69, Giza 96 and Australy manifested high osmotic values over both conditions. The improvement of osmotic pressure usually indicates higher water retention capacity and a lower rate of water loss with higher RWC\%. The cross-combination Giza $67 x$ PimaS6 followed by Giza 68 x PimaS6, Giza 86 x 10229, Giza 94 x Dandra and Giza 77 x PimaS6 recorded the lowest values of osmotic pressure under normal and stress conditions. These cross combinations showed some sort of tolerant water deficit. On the other side, the combinations Giza 45 x PimaS6 followed by Giza 86 x Dandra, Giza 69 x Dandra and Giza 69 x Australy showed the highest O.P.C.S values. Similar results was obtained by (Rahman et al., 2008). Chlorophyll contents as chlorophyll A and B plays a vital role in photosynthetic process which ultimately increase crop growth and yield. Data illustrated in Table 6 showed that under water deficit conditions.
Chlorophyll A and $\mathrm{B}$ values as $\mathrm{mg} \mathrm{g}^{-1}$ dry weight were reduced to the lowest amount. The parental cotton genotypes differed significantly for chlorophyll contents under normal and stress conditions. The highest values for chlorophyll A were recorded by Giza 77 followed by Giza 68 and Giza 86 under normal and stress conditions. On the other side, the lowest values were recorded for Giza 96 followed by Giza 69 and Minufy under normal and stress conditions. At the same time, the values of chlorophyll B were significantly different among cotton genotypes. The parents which, recorded high values of chlorophyll A under stress condition, also recorded high values of chlorophyll B. A higher values of chlorophyll content helps the plants to withstand water stress through better availabilities of chlorophyll, these results are in good way with those obtained by (Hamayun et al., 2010; Pirzad et al., 2011; Abdel-Kader et al., 2015a; Kannan et al., 2017). The highest values were recorded by Giza 77 followed by Giza 68, 10229 and PimaS6 under normal conditions, while Giza 77, Giza 68 and Giza 86 recorded the highest values under stress conditions. It is interest to note that genotypes with high values of carotenoids concentration under drought conditions recorded high values of chlorophyll A or/and B. The decrement of chlorophyll content under drought or water deficit stress could be related to photo oxidation resulting from oxidative stress, which may be formation of free radicals, which lead to causes to chlorophyll damage through the oxidative, which reduces photosynthetic process. Under stress conditions, carotenoids and other pigmentation may be absorption of the hurtful sub which formed as a result 9 of free radicals and avoid the chlorophyll from damage. Drought stress can also alter the tissue concentrations of chlorophyll and carotenoids. Proline is one of the osmoprotectants formed in tissues enable the plant to maintain low water potentials that allows additional water uptake from the stress condition, thus buffering the immediate effect of water deficit. Proline accumulation helps the plants to minimize the dehydration damage to the cell membrane. The results showed that, under water stress conditions, the genotypes showed significant decreased in metabolic factors, such as decreased in chlorophyll (A, B), carotenoids content and enhanced accumulation of proline (Din et al., 2011; Kannan et al., 2017). Accumulation of proline is a widespread plant response to water deficit. Proline accumulation is believed to play adaptive roles in plant stress tolerance. Water deficit has a positive increase in the leaf accumulated proline levels Table 6 . The parental genotypes showed significance differences in proline accumulated under normal and stress conditions. The parental genotypes Giza 77 followed by Giza 68 and Giza 86 recorded the highest values of proline accumulated in leaf under stress conditions. On the other side, parental genotypes which showed high values of proline accumulation under normal conditions gave the lowest values of proline under stress conditions. Similar results were obtained by (Kannan et al., 2017). 
Table 4. Proportional contribution of lines, testers and their interaction to total variance for water relations and leaves chemical composition under normal and water stress conditions

\begin{tabular}{lcccccccccc}
\hline Source & $\begin{array}{c}\text { Total water content } \\
(\boldsymbol{\%})\end{array}$ & \multicolumn{2}{c}{$\begin{array}{c}\text { Free water } \\
(\boldsymbol{\%})\end{array}$} & \multicolumn{2}{c}{$\begin{array}{c}\text { Bound water } \\
(\boldsymbol{\%})\end{array}$} & \multicolumn{2}{c}{$\begin{array}{c}\text { Leaf water deficit } \\
(\boldsymbol{\%})\end{array}$} & \multicolumn{2}{c}{$\begin{array}{c}\text { Relative water content } \\
(\boldsymbol{\%})\end{array}$} \\
\hline Lines & $\mathbf{N}$ & $\mathbf{S}$ & $\mathbf{N}$ & $\mathbf{S}$ & $\mathbf{N}$ & $\mathbf{S}$ & $\mathbf{N}$ & $\mathbf{S}$ & $\mathbf{N}$ & $\mathbf{S}$ \\
Tester & 35.04 & 17.76 & 23.51 & 21.81 & 20.24 & 16.74 & 29.43 & 17.05 & 19.60 & 16.78 \\
Lines $\mathrm{x}$ & 43.37 & 13.31 & 12.38 & 5.26 & 40.59 & 14.67 & 12.43 & 14.22 & 22.06 & 11.96 \\
Tester & 68.92 & 64.11 & 72.93 & 39.17 & 68.59 & 58.13 & 68.73 & 58.34 & 71.26 \\
\hline
\end{tabular}

$\mathrm{N}=$ normal irrigation and $\mathrm{S}=$ water stress

Table 4. continued

\begin{tabular}{|c|c|c|c|c|c|c|c|c|c|c|}
\hline \multirow[t]{2}{*}{ Source } & \multicolumn{2}{|c|}{$\begin{array}{c}\text { Osmotic pressure } \\
\text { (bar) }\end{array}$} & \multicolumn{2}{|c|}{$\begin{array}{c}\text { Chlorophyll A } \\
\left(\mathrm{mg} \mathrm{g}^{-1} \text { dwt) }\right.\end{array}$} & \multicolumn{2}{|c|}{$\begin{array}{l}\text { Chlorophyll B } \\
\left(\mathrm{mg} \mathrm{g}^{-1} \text { dwt) }\right.\end{array}$} & \multicolumn{2}{|c|}{$\begin{array}{l}\text { Carotenoides } \\
\left(\mathrm{mg} \mathrm{g}^{-1} \mathrm{dwt}\right)\end{array}$} & \multicolumn{2}{|c|}{$\begin{array}{c}\text { Proline } \\
\left(\mathrm{mg} \mathrm{g}^{-1} \text { fwt }\right)\end{array}$} \\
\hline & $\mathbf{N}$ & $\mathbf{S}$ & $\mathbf{N}$ & $\mathbf{S}$ & $\mathbf{N}$ & $\mathbf{S}$ & $\mathbf{N}$ & $\mathbf{S}$ & $\mathbf{N}$ & $\mathbf{S}$ \\
\hline Lines & 29.18 & 17.06 & 22.48 & 22.91 & 19.11 & 23.27 & 26.96 & 22.41 & 29.27 & 17.09 \\
\hline Tester & 12.75 & 14.28 & 6.58 & 6.79 & 6.71 & 1.63 & 8.11 & 11.84 & 12.36 & 14.20 \\
\hline $\begin{array}{l}\text { Lines } \quad \mathrm{X} \\
\text { Tester }\end{array}$ & 58.06 & 68.65 & 70.94 & 70.30 & 74.18 & 75.11 & 64.93 & 65.76 & 58.37 & 68.71 \\
\hline
\end{tabular}

$\mathrm{N}=$ normal irrigation and $\mathrm{S}=$ water stress

Table 5. Proportional contribution of lines, testers and their interaction to total variance for drought tolerance indices under normal and water stress conditions

\begin{tabular}{lcccccccccc}
\hline \multicolumn{1}{c}{ Source } & Tol & M.P. & H.M. & S.S.I. & G.M.P. & S.T.I. & Y.I. & Y.S.I & R.D.I & D.I. \\
\hline Lines & 43.50 & 12.88 & 11.55 & 42.83 & 12 & 42.79 & 13.78 & 42.79 & 42.82 & 25.21 \\
Tester & 5.12 & 14.03 & 16.87 & 9.61 & 15.55 & 9.62 & 19.68 & 9.62 & 9.63 & 18 \\
Lines x Tester & 51.38 & 73.09 & 71.58 & 47.56 & 72.45 & 47.59 & 66.54 & 47.59 & 47.56 & 56.78 \\
\hline
\end{tabular}

$\mathrm{N}=$ normal irrigation and $\mathrm{S}=$ water stress

Different drought tolerance indices were calculated on the basis of yield of the genotypes under well irrigated (Yp) and water deficit conditions (Ys) as shown in Table 7. Data revealed that greater the value of tolerance index larger the yield reduction under water deficit conditions and higher the stress sensitivity. The genotypes, parents and hybrids were significantly differences. The parental genotypes Giza 96 followed by Minufy and 10229 showed the highest reduction in yield under water deficit conditions. The cross combinations which involved Giza 96 as a common parent recorded higher values of tolerance index. In the same time, the cross combination Minufy $\mathrm{x}$ Australy showed the higher values of yield reduction followed by the combinations Giza 67 x Australy and Giza 69 x Australy. On the reverse trend, stress tolerance index (STI), which can be used to identify genotypes that produce high yield under stress and nonstress conditions. A large value of stress tolerance index (STI) show more tolerant for stress. Other yield-based estimates of stress resistance are mean productivity, geometric mean and 10 harmonic mean. The geometric mean is often used by breeders interested in relative performance since water deficit stress can vary in severity in field environment over time. Stress sensitive index (SSI) showed low amount values (less than unity), indicated high tolerance of genotypes to water deficit (Zangi, 2005). To determine the most desirable drought tolerance criteria, correlation coefficient between yield in well irrigation, yield in stress and other tolerant indices were calculated Table 8. The yield (Yn) under well irrigated conditions have a strong association with (Ys) yield under stress conditions and with most other tolerant indices depicting that high yield potential under well conditions gave superior yield under stress conditions and the loss of yield was relatively small. Therefore, indirect selection for stress environment based on performance of irrigated conditions would be effective (Anwar et al., 2011). Data illustrated in Table 8 revealed that a larger value of tolerant index show more sensitivity to water deficit since correlation coefficients between tolerant index and other yield indices were negative and significant. Thus, a smaller value of tolerant index is favored to selection, based on tolerant index favor genotypes with low yield potential and high yield under stress conditions. Similar results were obtained by (Zangi, 2005). 

conditions

\begin{tabular}{|c|c|c|c|c|c|c|c|c|c|c|}
\hline \multirow[t]{2}{*}{ Genotypes } & \multicolumn{2}{|c|}{$\begin{array}{c}\text { Total water content } \\
(\%)\end{array}$} & \multicolumn{2}{|c|}{$\begin{array}{c}\text { Free water } \\
(\%)\end{array}$} & \multicolumn{2}{|c|}{$\begin{array}{c}\text { Bound water } \\
(\%)\end{array}$} & \multicolumn{2}{|c|}{$\begin{array}{c}\text { Leaf water deficit } \\
(\%)\end{array}$} & \multirow{2}{*}{$\begin{array}{l}\text { Relative } \\
\text { content }(\%) \\
\mathbf{N}\end{array}$} & \multirow{2}{*}{$\begin{array}{c}\text { water } \\
\text { S }\end{array}$} \\
\hline & $\mathbf{N}$ & $\mathbf{S}$ & $\mathbf{N}$ & $\mathbf{S}$ & $\mathbf{N}$ & $\mathbf{S}$ & $\mathbf{N}$ & $\mathbf{S}$ & & \\
\hline L1- Giza 45 & 77.77 & 67.69 & 10.17 & 9.21 & 67.6 & 58.48 & 10.33 & 8.74 & 69.85 & 60.82 \\
\hline L2- Minufy & 77.4 & 63.78 & 10.1 & 8.68 & 67.3 & 55.1 & 10.07 & 8.06 & 68.98 & 56.84 \\
\hline L3- Giza 67 & 79.01 & 66.65 & 10.51 & 9.22 & 68.5 & 57.43 & 9.08 & 7.28 & 70.21 & 59.23 \\
\hline L4- Giza 68 & 79.54 & 65.82 & 10.6 & 9.12 & 68.95 & 56.7 & 8.17 & 6.5 & 70.1 & 58.01 \\
\hline L5- Giza 86 & 78.76 & 65.57 & 10.49 & 9.08 & 68.27 & 56.49 & 9.35 & 7.44 & 70.22 & 58.46 \\
\hline L6- Giza 77 & 79.02 & 66.32 & 10.55 & 9.2 & 68.47 & 57.12 & 8.4 & 6.74 & 70.32 & 59.02 \\
\hline L7- Giza 94 & 78.53 & 65.69 & 10.42 & 9.07 & 68.11 & 56.62 & 9.34 & 7.8 & 69.41 & 58.06 \\
\hline L8- Giza 96 & 76.05 & 65.17 & 9.37 & 8.38 & 66.68 & 56.79 & 11.37 & 8.77 & 66.95 & 57.37 \\
\hline L9- Giza 69 & 75.65 & 65.19 & 9.56 & 8.59 & 66.09 & 56.6 & 10.98 & 8.66 & 67.61 & 58.26 \\
\hline T1- Dandra & 76.97 & 67.43 & 9.67 & 8.82 & 67.3 & 58.61 & 10.87 & 8.91 & 66.87 & 58.6 \\
\hline T2- Pima S6 & 77.72 & 66.49 & 10.22 & 9.09 & 67.5 & 57.4 & 10.08 & 8.16 & 69.58 & 59.53 \\
\hline T3- Australy & 76.94 & 65.56 & 9.9 & 8.78 & 67.04 & 56.78 & 10.35 & 8.59 & 68.14 & 58.05 \\
\hline T4- 10229 & 78.45 & 65.93 & 10.28 & 8.99 & 68.18 & 56.94 & 10.01 & 8.33 & 69.81 & 58.66 \\
\hline Giza 45 x Dandra & 83.13 & 69.34 & 11.21 & 9.1 & 71.92 & 60.24 & 8.76 & 10.68 & 75.72 & 61.4 \\
\hline Giza 45 x Pima S6 & 79.6 & 66.49 & 10.32 & 8.36 & 69.28 & 58.13 & 10.1 & 11.86 & 70.12 & 56.8 \\
\hline Giza 45 x Australy & 84.3 & 66.89 & 11.36 & 8.76 & 72.94 & 58.13 & 9.32 & 11.69 & 76.74 & 59.14 \\
\hline Giza 45 x 10229 & 88.25 & 72.19 & 12.07 & 9.67 & 76.19 & 62.53 & 7.96 & 10.02 & 79.64 & 63.39 \\
\hline Minufy x Dandra & 87.91 & 72.52 & 12.22 & 9.54 & 75.69 & 62.98 & 7.3 & 9.85 & 82.2 & 63.67 \\
\hline Minufy x Pima S6 & 85.63 & 69.93 & 11.59 & 9.23 & 74.04 & 60.7 & 8.36 & 10.59 & 77.61 & 61.63 \\
\hline Minufy x Australy & 88.85 & 71.66 & 12.15 & 9.42 & 76.7 & 62.24 & 7.76 & 10.08 & 81.48 & 62.89 \\
\hline Minufy x 10229 & 86.28 & 70.34 & 11.84 & 9.43 & 74.44 & 60.91 & 8.62 & 10.53 & 77.75 & 61.63 \\
\hline Giza 67 x Dandra & 87.75 & 72.29 & 12.1 & 9.67 & 75.65 & 62.63 & 7.33 & 9.99 & 79.54 & 63.27 \\
\hline Giza 67 x Pima S6 & 88.61 & 71.68 & 11.81 & 9.28 & 76.8 & 62.4 & 7.78 & 10.09 & 79.95 & 62.52 \\
\hline Giza 67 x Australy & 88.27 & 71.02 & 12.26 & 9.49 & 76.01 & 61.53 & 7.99 & 10.29 & 80.75 & 62.14 \\
\hline Giza 67 x 10229 & 90.62 & 70.9 & 12.34 & 9.46 & 78.28 & 61.44 & 7.61 & 10.43 & 81.05 & 63.69 \\
\hline Giza 68 x Dandra & 83.12 & 67.33 & 11.41 & 9 & 71.71 & 58.33 & 8.82 & 11.57 & 74.23 & 58.38 \\
\hline Giza 68 x Pima S6 & 88.51 & 70.79 & 11.93 & 9.33 & 76.58 & 61.46 & 7.84 & 10.41 & 79.75 & 62.03 \\
\hline Giza 68 x Australy & 89.6 & 73.76 & 11.91 & 9.32 & 77.69 & 64.44 & 7.47 & 9.17 & 81.26 & 63.11 \\
\hline Giza 68 x 10229 & 88.07 & 70.56 & 11.23 & 8.74 & 76.84 & 61.82 & 7.85 & 10.33 & 78.5 & 61.15 \\
\hline Giza 86 x Dandra & 83.85 & 68.17 & 11.5 & 9.11 & 72.35 & 59.06 & 8.54 & 11.16 & 75.72 & 64.48 \\
\hline Giza 86 x Pima S6 & 90.79 & 71.39 & 11.94 & 9.56 & 75.38 & 61.84 & 8.25 & 10.27 & 77.93 & 61.94 \\
\hline Giza 86 x Australy & 85.78 & 69.5 & 11.58 & 9.18 & 74.2 & 60.32 & 8.75 & 10.7 & 77.76 & 61.25 \\
\hline Giza 86 x 10229 & 89.41 & 71.8 & 12.33 & 9.45 & 77.09 & 62.36 & 7.6 & 10.04 & 83.43 & 63.66 \\
\hline Giza 77 x Dandra & 81.75 & 66.73 & 11.24 & 8.93 & 70.51 & 57.8 & 9.33 & 12.01 & 73.72 & 58.41 \\
\hline Giza 77 x Pima S6 & 89.54 & 73.2 & 12.26 & 9.81 & 77.28 & 63.39 & 7.55 & 9.62 & 80.79 & 64.29 \\
\hline Giza 77 x Australy & 85.79 & 70.15 & 11.37 & 9.07 & 74.43 & 61.09 & 8.74 & 10.51 & 76.93 & 61.16 \\
\hline Giza 77 x 10229 & 90.6 & 71.33 & 12.19 & 9.38 & 78.42 & 61.95 & 7.65 & 10.15 & 81.74 & 62.61 \\
\hline Giza 94 x Dandra & 88.02 & 73.29 & 12.46 & 9.78 & 75.56 & 63.51 & 7.31 & 9.39 & 81.7 & 63.81 \\
\hline Giza 94 x Pima S6 & 88.58 & 70.21 & 12.18 & 9.41 & 76.41 & 60.8 & 7.86 & 10.56 & 80.17 & 61.52 \\
\hline Giza 94 x Australy & 86.28 & 69.63 & 11.63 & 9.14 & 74.65 & 60.49 & 8.57 & 10.66 & 77.87 & 61.09 \\
\hline Giza 94 x 10229 & 88.63 & 70.83 & 11.48 & 8.93 & 77.15 & 61.9 & 7.71 & 10.32 & 77.97 & 60.57 \\
\hline Giza 96 x Dandra & 80.05 & 66.04 & 10.2 & 8.17 & 69.85 & 57.88 & 9.87 & 12.06 & 71.44 & 57.17 \\
\hline Giza 96 x Pima S6 & 84.33 & 67.39 & 11.53 & 8.97 & 72.8 & 58.43 & 9.35 & 11.62 & 75.52 & 58.6 \\
\hline Giza 96 x Australy & 88.71 & 72.52 & 12.41 & 9.7 & 76.3 & 62.83 & 7.87 & 9.75 & 81.89 & 59.81 \\
\hline Giza 96 x 10229 & 87.32 & 71.68 & 12.27 & 9.47 & 78.53 & 62.21 & 7.58 & 10.11 & 82.24 & 63.2 \\
\hline Giza 69 x Dandra & 81.09 & 67.16 & 10.59 & 8.52 & 70.51 & 58.64 & 9.47 & 11.51 & 73.46 & 59.07 \\
\hline Giza 69 x Pima S6 & 84.33 & 66.67 & 10.77 & 8.25 & 73.57 & 58.42 & 9.17 & 11.69 & 75.21 & 57.72 \\
\hline Giza 69 x Australy & 89.13 & 71.62 & 12.29 & 9.59 & 76.84 & 62.03 & 7.69 & 10.14 & 80.15 & 62.16 \\
\hline Giza 69 x 10229 & 87.65 & 70.9 & 11.58 & 9.17 & 76.07 & 61.74 & 8.07 & 10.26 & 78.59 & 61.81 \\
\hline$L S D(0.05)$ & 1.73 & 1.49 & 0.35 & 0.24 & 1.52 & 1.33 & 0.497 & 0.53 & 2.48 & 1.77 \\
\hline
\end{tabular}


Table 6. continued

\begin{tabular}{|c|c|c|c|c|c|c|c|c|c|c|}
\hline \multirow[t]{2}{*}{ Genotypes } & \multicolumn{2}{|c|}{$\begin{array}{c}\text { Osmotic pressure } \\
\text { (bar) }\end{array}$} & \multicolumn{2}{|c|}{$\begin{array}{c}\text { Chlorophyll A } \\
\text { (mg g-1 dwt) }\end{array}$} & \multicolumn{2}{|c|}{$\begin{array}{c}\text { Chlorophyll B } \\
\left(\mathrm{mg} \mathrm{g}^{-1} \text { dwt) }\right.\end{array}$} & \multicolumn{2}{|c|}{$\begin{array}{l}\text { Carotenoides } \\
\left(\mathrm{mg} \mathrm{g}^{-1} \mathrm{dwt}\right)\end{array}$} & \multicolumn{2}{|c|}{$\begin{array}{c}\text { Proline } \\
\left(\mathrm{mg} \mathrm{g}^{-1} \text { fwt }\right)\end{array}$} \\
\hline & $\mathbf{N}$ & $\mathbf{S}$ & $\mathbf{N}$ & $\mathbf{S}$ & $\mathbf{N}$ & $\mathbf{S}$ & $\mathbf{N}$ & $\mathbf{S}$ & $\mathbf{N}$ & $\mathbf{S}$ \\
\hline L1- Giza 45 & 4.72 & 3.81 & 3.2 & 3.01 & 1.28 & 1.12 & 1.44 & 1.33 & 353.45 & 665.76 \\
\hline L2- Minufy & 4.81 & 3.98 & 3.18 & 2.99 & 1.27 & 1.15 & 1.39 & 1.34 & 355.99 & 675.36 \\
\hline L3- Giza 67 & 4.29 & 3.67 & 3.34 & 3.13 & 1.31 & 1.23 & 1.50 & 1.31 & 343.48 & 684.48 \\
\hline L4- Giza 68 & 4.14 & 3.37 & 3.51 & 3.07 & 1.33 & 1.24 & 1.56 & 1.37 & 341.61 & 685.33 \\
\hline L5- Giza 86 & 4.43 & 3.61 & 3.45 & 3.16 & 1.32 & 1.23 & 1.52 & 1.36 & 343.84 & 685.82 \\
\hline L6- Giza 77 & 4.18 & 3.37 & 3.56 & 3.09 & 1.34 & 1.24 & 1.57 & 1.37 & 343.51 & 684.66 \\
\hline L7- Giza 94 & 4.51 & 3.84 & 3.26 & 3.05 & 1.3 & 1.22 & 1.47 & 1.35 & 345.54 & 679.6 \\
\hline L8- Giza 96 & 5.7 & 4.78 & 3.01 & 2.93 & 1.37 & 1.15 & 1.38 & 1.26 & 363.67 & 683.18 \\
\hline L9- Giza 69 & 5.48 & 4.64 & 3.07 & 3.00 & 1.4 & 1.17 & 1.44 & 1.29 & 364.22 & 680.53 \\
\hline T1- Dandra & 5.22 & 4.34 & 3.17 & 3.14 & 1.38 & 1.18 & 1.47 & 1.29 & 360.71 & 672.25 \\
\hline T2- Pima S6 & 4.71 & 4.1 & 3.39 & 3.1 & 1.41 & 1.21 & 1.55 & 1.35 & 353.06 & 676.8 \\
\hline T3- Australy & 5.12 & 4.38 & 3.23 & 3.07 & 1.41 & 1.19 & 1.5 & 1.32 & 359.91 & 675.56 \\
\hline T4- 10229 & 4.57 & 4.04 & 3.44 & 3.06 & 1.42 & 1.22 & 1.57 & 1.36 & 350.26 & 675.04 \\
\hline Giza 45 x Dandra & 3.62 & 5.36 & 3.59 & 3.04 & 1.39 & 1.2 & 1.6 & 1.35 & 327.84 & 564.34 \\
\hline Giza 45 x Pima S6 & 4.17 & 5.94 & 3.3 & 2.77 & 1.29 & 1.09 & 1.53 & 1.29 & 393.18 & 626.99 \\
\hline Giza 45 x Australy & 3.85 & 5.86 & 3.37 & 2.85 & 1.35 & 1.16 & 1.5 & 1.27 & 357.44 & 618 \\
\hline Giza 45 x 10229 & 3.29 & 5.02 & 4.07 & 3.43 & 1.58 & 1.34 & 1.79 & 1.5 & 285.55 & 529.72 \\
\hline Minufy x Dandra & 3.22 & 5.06 & 4.1 & 3.42 & 1.53 & 1.32 & 1.82 & 1.52 & 250.66 & 520.46 \\
\hline Minufy x Pima S6 & 3.46 & 5.31 & 3.73 & 3.15 & 1.44 & 1.24 & 1.67 & 1.41 & 306.7 & 559.85 \\
\hline Minufy x Australy & 3.2 & 5.06 & 3.96 & 3.36 & 1.51 & 1.3 & 1.78 & 1.5 & 274.97 & 532.89 \\
\hline Minufy x 10229 & 3.56 & 5.28 & 3.85 & 3.26 & 1.53 & 1.3 & 1.7 & 1.44 & 320.71 & 556.41 \\
\hline Giza 67 x Dandra & 3.03 & 5.01 & 4 & 3.36 & 1.5 & 1.31 & 1.77 & 1.48 & 252.25 & 527.87 \\
\hline Giza 67 x Pima S6 & 3.02 & 4.94 & 3.88 & 3.29 & 1.47 & 1.26 & 1.73 & 1.47 & 276.3 & 533.15 \\
\hline Giza 67 x Australy & 3.31 & 5.16 & 3.85 & 3.26 & 1.5 & 1.28 & 1.69 & 1.44 & 287.4 & 543.72 \\
\hline Giza 67 x 10229 & 3.15 & 5.22 & 3.93 & 3.28 & 1.52 & 1.3 & 1.72 & 1.44 & 267.04 & 551.13 \\
\hline Giza 68 x Dandra & 3.65 & 5.79 & 3.6 & 3.02 & 1.42 & 1.24 & 1.57 & 1.31 & 331.28 & 611.4 \\
\hline Giza 68 x Pima S6 & 3.09 & 4.6 & 3.86 & 3.26 & 1.48 & 1.28 & 1.7 & 1.44 & 279.21 & 550.07 \\
\hline Giza 68 x Australy & 3.24 & 5.21 & 3.97 & 3.31 & 1.45 & 1.22 & 1.85 & 1.54 & 280 & 545.84 \\
\hline Giza 68 x 10229 & 3.24 & 5.18 & 3.68 & 3.09 & 1.36 & 1.15 & 1.7 & 1.42 & 259.91 & 484.52 \\
\hline Giza 86 x Dandra & 3.53 & 5.59 & 3.67 & 3.1 & 1.43 & 1.26 & 1.61 & 1.36 & 316.48 & 589.72 \\
\hline Giza 86 x Pima S6 & 3.41 & 5.15 & 3.96 & 3.34 & 1.56 & 1.32 & 1.72 & 1.45 & 300.88 & 542.67 \\
\hline Giza 86 x Australy & 3.62 & 5.36 & 3.68 & 3.11 & 1.44 & 1.23 & 1.66 & 1.4 & 327.58 & 565.4 \\
\hline Giza 86 x 10229 & 3.15 & 5.03 & 3.84 & 3.22 & 1.46 & 1.24 & 1.72 & 1.44 & 266.78 & 530.51 \\
\hline Giza 77 x Dandra & 3.19 & 5.08 & 3.51 & 2.98 & 1.39 & 1.23 & 1.56 & 1.32 & 358.24 & 634.65 \\
\hline Giza 77 x Pima S6 & 3.13 & 4.83 & 4.14 & 3.5 & 1.59 & 1.36 & 1.82 & 1.54 & 378.79 & 637.3 \\
\hline Giza 77 x Australy & 3.62 & 5.27 & 3.77 & 3.17 & 1.46 & 1.23 & 1.68 & 1.42 & 327.05 & 555.62 \\
\hline Giza 77 x 10229 & 3.15 & 5.09 & 3.93 & 3.33 & 1.51 & 1.3 & 1.75 & 1.48 & 269.16 & 536.33 \\
\hline Giza 94 x Dandra & 3.02 & 4.71 & 4.11 & 3.48 & 1.55 & 1.35 & 1.78 & 1.52 & 251.19 & 496.15 \\
\hline Giza 94 x Pima S6 & 3.26 & 5.29 & 3.89 & 3.25 & 1.51 & 1.3 & 1.72 & 1.43 & 280.53 & 558.26 \\
\hline Giza 94 x Australy & 3.54 & 5.34 & 3.79 & 3.2 & 1.48 & 1.27 & 1.69 & 1.42 & 318.06 & 563.29 \\
\hline Giza 94 x 10229 & 3.19 & 5.17 & 3.64 & 3.09 & 1.35 & 1.17 & 1.69 & 1.43 & 272.33 & 545.31 \\
\hline Giza 96 x Dandra & 4.08 & 6.04 & 3.3 & 2.76 & 1.27 & 1.08 & 1.51 & 1.26 & 264.14 & 508.57 \\
\hline Giza 96 x Pima S6 & 3.86 & 5.82 & 3.58 & 3.01 & 1.45 & 1.24 & 1.57 & 1.32 & 359.3 & 614.3 \\
\hline Giza 96 x Australy & 3.25 & 4.89 & 3.98 & 3.38 & 1.54 & 1.32 & 1.75 & 1.48 & 280.79 & 515.44 \\
\hline Giza 96 x 10229 & 3.12 & 5.06 & 3.88 & 3.28 & 1.49 & 1.27 & 1.73 & 1.47 & 265.46 & 534.21 \\
\hline Giza 69 x Dandra & 3.92 & 5.76 & 3.45 & 2.92 & 1.32 & 1.14 & 1.61 & 1.35 & 365.38 & 608.22 \\
\hline Giza 69 x Pima S6 & 3.79 & 5.85 & 3.34 & 2.8 & 1.29 & 1.1 & 1.53 & 1.28 & 349.51 & 617.74 \\
\hline Giza 69 x Australy & 3.86 & 6.01 & 3.97 & 3.35 & 1.54 & 1.32 & 1.73 & 1.46 & 271.54 & 536.06 \\
\hline Giza $69 \times 10229$ & 3.34 & 5.14 & 3.87 & 3.23 & 1.48 & 1.25 & 1.6 & 1.46 & 291.63 & 564.34 \\
\hline$L S D(0.05)$ & 0.18 & 0.25 & 0.13 & 0.11 & 0.04 & 0.03 & 0.06 & 0.05 & 22.25 & 24.47 \\
\hline$L S D(0.01)$ & 0.24 & 0.33 & 0.18 & 0.14 & 0.05 & 0.04 & 0.08 & 0.07 & 29.55 & 32.50 \\
\hline
\end{tabular}


Table 7. Mean values of drought tolerance indices in cotton

\begin{tabular}{|c|c|c|c|c|c|c|c|c|c|c|}
\hline Parents & Tol & M.P. & H.M. & S.S.I. & G.M.P & S.T.I. & Y.I. & Y.S.I & R.D.I & D.I. \\
\hline L1- Giza 45 & 18.73 & 68.23 & 66.79 & 1.02 & 67.5 & 0.76 & 0.9 & 0.76 & 0.99 & 0.69 \\
\hline L2- Minufy & 28.53 & 68.19 & 65.21 & 1.49 & 66.68 & 0.65 & 0.82 & 0.65 & 0.85 & 0.54 \\
\hline L3- Giza 67 & 11.35 & 84 & 83.61 & 0.55 & 83.8 & 0.87 & 1.19 & 0.87 & 1.14 & 1.04 \\
\hline L4- Giza 68 & 14.99 & 77.02 & 76.26 & 0.77 & 76.64 & 0.82 & 1.06 & 0.82 & 1.07 & 0.87 \\
\hline L5- Giza 86 & 19.15 & 67.03 & 65.66 & 1.08 & 66.35 & 0.75 & 0.88 & 0.75 & 0.98 & 0.66 \\
\hline L6- Giza 77 & 17.82 & 65.22 & 63.86 & 1.03 & 64.53 & 0.76 & 0.86 & 0.76 & 0.99 & 0.66 \\
\hline L7- Giza 94 & 11.53 & 78.34 & 77.91 & 0.59 & 78.13 & 0.86 & 1.11 & 0.86 & 1.12 & 0.96 \\
\hline L8- Giza 96 & 53.22 & 71.49 & 61.57 & 2.34 & 66.34 & 0.46 & 0.68 & 0.46 & 0.6 & 0.31 \\
\hline L9- Giza 69 & 15.83 & 67.36 & 66.33 & 0.92 & 66.84 & 0.79 & 0.91 & 0.79 & 1.03 & 0.72 \\
\hline T1- Dandra & 13.59 & 59.4 & 58.6 & 0.89 & 59 & 0.79 & 0.8 & 0.79 & 1.03 & 0.64 \\
\hline T2- Pima S6 & 15.94 & 72.69 & 71.79 & 0.86 & 72.24 & 0.8 & 0.99 & 0.8 & 1.04 & 0.79 \\
\hline T3- Australy & 15.47 & 62.89 & 61.92 & 0.93 & 62.41 & 0.78 & 0.84 & 0.78 & 1.02 & 0.66 \\
\hline T4- 10229 & 24.26 & 34.97 & 30.71 & 2.2 & 32.77 & 0.49 & 0.35 & 0.49 & 0.64 & 0.17 \\
\hline Giza 45 x Dandra & 18.96 & 80.38 & 79.24 & 0.91 & 79.8 & 0.79 & 1.08 & 0.79 & 1.03 & 0.85 \\
\hline Giza 45 x Pima S6 & 11.82 & 83.51 & 83.09 & 0.57 & 83.3 & 0.87 & 1.18 & 0.87 & 1.13 & 1.03 \\
\hline Giza 45 x Australy & 12.57 & 71.42 & 70.86 & 0.7 & 71.14 & 0.84 & 0.99 & 0.84 & 1.09 & 0.83 \\
\hline Giza 45 x 10229 & 18.57 & 64.73 & 63.14 & 1.05 & 63.92 & 0.76 & 0.85 & 0.76 & 0.98 & 0.64 \\
\hline Minufy x Dandra & 20.16 & 77.99 & 76.53 & 0.97 & 77.26 & 0.77 & 1.04 & 0.77 & 1.01 & 0.81 \\
\hline Minufy x Pima S6 & 24.61 & 77.34 & 75.36 & 1.19 & 76.35 & 0.72 & 0.99 & 0.72 & 0.94 & 0.72 \\
\hline Minufy x Australy & 56.2 & 87.57 & 78.23 & 2.08 & 82.74 & 0.52 & 0.91 & 0.52 & 0.67 & 0.47 \\
\hline Minufy x 10229 & 23.91 & 81.95 & 80.1 & 1.07 & 81.01 & 0.75 & 1.07 & 0.75 & 0.98 & 0.8 \\
\hline Giza 67 x Dandra & 11.83 & 69.08 & 68.57 & 0.69 & 68.82 & 0.84 & 0.96 & 0.84 & 1.09 & 0.81 \\
\hline Giza 67 x Pima S6 & 17.42 & 74.15 & 73.06 & 0.9 & 73.6 & 0.79 & 1 & 0.79 & 1.03 & 0.79 \\
\hline Giza 67 x Australy & 39.07 & 91.41 & 87.07 & 1.51 & 89.21 & 0.65 & 1.1 & 0.65 & 0.85 & 0.72 \\
\hline Giza 67 x 10229 & 12.95 & 73.05 & 72.45 & 0.71 & 72.75 & 0.84 & 1.02 & 0.84 & 1.09 & 0.85 \\
\hline Giza 68 x Dandra & 24.2 & 81.78 & 79.98 & 1.11 & 80.87 & 0.74 & 1.06 & 0.74 & 0.97 & 0.79 \\
\hline Giza 68 x Pima S6 & 24.97 & 66.61 & 64.25 & 1.35 & 65.42 & 0.69 & 0.83 & 0.69 & 0.89 & 0.57 \\
\hline Giza 68 x Australy & 32.01 & 72.04 & 68.48 & 1.57 & 70.24 & 0.64 & 0.85 & 0.64 & 0.83 & 0.54 \\
\hline Giza 68 x 10229 & 18.11 & 80.58 & 79.47 & 0.86 & 80.02 & 0.8 & 1.09 & 0.8 & 1.04 & 0.87 \\
\hline Giza 86 x Dandra & 23.2 & 110.79 & 109.55 & 0.83 & 110.17 & 0.81 & 1.51 & 0.81 & 1.05 & 1.23 \\
\hline Giza 86 x Pima S6 & 26.69 & 70.91 & 68.26 & 1.37 & 69.57 & 0.68 & 0.88 & 0.68 & 0.89 & 0.61 \\
\hline Giza 86 x Australy & 21.75 & 84.45 & 82.91 & 0.98 & 83.67 & 0.77 & 1.12 & 0.77 & 1.01 & 0.87 \\
\hline Giza 86 x 10229 & 19.51 & 73.61 & 72.27 & 1 & 72.93 & 0.77 & 0.97 & 0.77 & 1 & 0.75 \\
\hline Giza 77 x Dandra & 12.25 & 79.69 & 79.2 & 0.61 & 79.44 & 0.86 & 1.12 & 0.86 & 1.12 & 0.96 \\
\hline Giza 77 x Pima S6 & 11.75 & 87.12 & 86.72 & 0.54 & 86.92 & 0.87 & 1.24 & 0.87 & 1.14 & 1.08 \\
\hline Giza 77 x Australy & 20.07 & 78.38 & 76.94 & 0.97 & 77.66 & 0.77 & 1.04 & 0.77 & 1.01 & 0.81 \\
\hline Giza 77 x 10229 & 20.62 & 57.57 & 55.54 & 1.27 & 56.54 & 0.71 & 0.72 & 0.71 & 0.92 & 0.51 \\
\hline Giza 94 x Dandra & 15.72 & 77.04 & 76.22 & 0.8 & 76.63 & 0.81 & 1.06 & 0.81 & 1.06 & 0.86 \\
\hline Giza 94 x Pima S6 & 13.26 & 72.02 & 71.4 & 0.72 & 71.71 & 0.83 & 1 & 0.83 & 1.08 & 0.83 \\
\hline Giza 94 x Australy & 27.7 & 74.14 & 71.31 & 1.33 & 72.71 & 0.69 & 0.92 & 0.69 & 0.9 & 0.64 \\
\hline Giza 94 x 10229 & 19.02 & 77.6 & 76.37 & 0.92 & 76.98 & 0.79 & 1.04 & 0.79 & 1.02 & 0.81 \\
\hline Giza 96 x Dandra & 40 & 93.83 & 89.55 & 1.52 & 91.66 & 0.65 & 1.13 & 0.65 & 0.84 & 0.73 \\
\hline Giza 96 x Pima S6 & 23.87 & 66.59 & 64.43 & 1.3 & 65.5 & 0.7 & 0.83 & 0.7 & 0.91 & 0.58 \\
\hline Giza 96 x Australy & 32.16 & 72.04 & 68.41 & 1.57 & 70.2 & 0.64 & 0.85 & 0.64 & 0.83 & 0.54 \\
\hline Giza 96 x 10229 & 36.17 & 71.06 & 66.43 & 1.75 & 68.7 & 0.59 & 0.81 & 0.59 & 0.77 & 0.48 \\
\hline Giza 69 x Dandra & 14.27 & 64.43 & 63.59 & 0.85 & 64.01 & 0.8 & 0.87 & 0.8 & 1.05 & 0.7 \\
\hline Giza 69 x Pima S6 & 15.26 & 87.52 & 86.83 & 0.68 & 87.18 & 0.84 & 1.22 & 0.84 & 1.1 & 1.02 \\
\hline Giza 69 x Australy & 37.78 & 69.53 & 64.29 & 1.83 & 66.85 & 0.58 & 0.77 & 0.58 & 0.75 & 0.45 \\
\hline Giza 69 x 10229 & 16.26 & 66.17 & 65.14 & 0.92 & 65.65 & 0.79 & 0.89 & 0.79 & 1.02 & 0.69 \\
\hline$L S D(0.05)$ & 9.47 & 10.81 & 10.58 & 0.37 & 10.66 & 0.09 & 0.16 & 0.09 & 0.11 & 0.17 \\
\hline
\end{tabular}


Table 8. Correlation coefficients between yield in normal and stress conditions with drought tolerance indices

\begin{tabular}{|c|c|c|c|c|c|c|c|c|c|c|c|}
\hline Traits & $\begin{array}{c}\text { Seed } \\
\text { cotton } \\
\text { yield } \\
\text { (stress) } \\
\end{array}$ & $\begin{array}{c}\text { Seed } \\
\text { cotton } \\
\text { yield } \\
\text { (normal) } \\
\end{array}$ & $\begin{array}{c}\text { Tolerance } \\
\text { index }\end{array}$ & $\begin{array}{c}\text { Mean } \\
\text { productivity }\end{array}$ & $\begin{array}{c}\text { Harmonic } \\
\text { mean }\end{array}$ & $\begin{array}{c}\text { Stress } \\
\text { susceptibility } \\
\text { index }\end{array}$ & $\begin{array}{c}\text { Geometric } \\
\text { mean } \\
\text { productivity }\end{array}$ & $\begin{array}{c}\text { tolerance } \\
\text { index }\end{array}$ & $\begin{array}{l}\text { Yield } \\
\text { index }\end{array}$ & $\begin{array}{c}\text { Yield } \\
\text { stability } \\
\text { index }\end{array}$ & $\begin{array}{c}\text { Relative } \\
\text { drought } \\
\text { index }\end{array}$ \\
\hline $\begin{array}{l}\text { Seed cotton } \\
\text { yield (normal) }\end{array}$ & $0.606^{* *}$ & & & & & & & & & & \\
\hline $\begin{array}{l}\text { Tolerance } \\
\text { index }\end{array}$ & $-0.307 *$ & $0.511 * *$ & & & & & & & & & \\
\hline $\begin{array}{l}\text { Mean } \\
\text { productivity }\end{array}$ & $0.856^{* *}$ & $0.921 * *$ & 0.137 & & & & & & & & \\
\hline $\begin{array}{l}\text { Harmonic } \\
\text { mean }\end{array}$ & $0.924 * *$ & $0.840 * *$ & -0.036 & $0.984 * *$ & & & & & & & \\
\hline Stress & & & & & & & & & & & \\
\hline $\begin{array}{l}\text { susceptibility } \\
\text { index }\end{array}$ & $-0.679 * *$ & 0.111 & $0.894 * *$ & -0.276 & $-0.433 * *$ & & & & & & \\
\hline $\begin{array}{l}\text { Geometric } \\
\text { mean } \\
\text { productivity }\end{array}$ & $0.895 * *$ & $0.882 * *$ & 0.047 & $0.996 * *$ & $0.996 * *$ & $-0.559 *$ & & & & & \\
\hline $\begin{array}{l}\text { Tolerance } \\
\text { index }\end{array}$ & $0.679 * *$ & -0.112 & $-0.899 * *$ & 0.276 & $0.433^{* *}$ & $0.999 * *$ & $0.359 * *$ & & & & \\
\hline Yield index & $0.975^{* *}$ & $0.663 * *$ & $-0.304 *$ & $0.902 * *$ & $0.962 * *$ & $-0.656^{* *}$ & $0.937 * *$ & $0.655^{* *}$ & & & \\
\hline $\begin{array}{l}\text { Yield stability } \\
\text { index }\end{array}$ & $0.679 * *$ & -0.112 & $-0.894 * *$ & 0.276 & $0.433^{* *}$ & $-0.999 * *$ & $0.359 *$ & $1 * *$ & $0.655^{* *}$ & & \\
\hline $\begin{array}{l}\text { Relative } \\
\text { drought index }\end{array}$ & $0.679 * *$ & -0.111 & $-0.894 * *$ & 0.276 & $0.433^{* *}$ & $-0.999 * *$ & $0.359^{*}$ & $1 * *$ & $0.655^{* *}$ & $1 * *$ & \\
\hline Drought index & $0.930 * *$ & $0.367 * *$ & $-0.609 * *$ & $0.699 * *$ & $0.807 * *$ & $-0.863 * *$ & $0.758^{* *} *$ & $0.863 * *$ & $0.937 * *$ & $0.863 * *$ & $0.863^{* *}$ \\
\hline
\end{tabular}

*,** Significant and highly significant at 0.05 and 0.01 level of probability respectively

\section{CONCLUSIONS}

In conclusion, the parental genotypes Giza 96 showed the highest reduction in yield under water deficit conditions, followed by, Minufy x Australy followed by the combinations Giza 67 x Australy. Among the male parents, the Russian genotype 10229 recorded the best GCA values for most water relationship characters. While, the female parents, the old Egyptian genotype 12 Giza 67 recorded the best values and exhibited good general combined for most water relationship characters. In addition, the cross combinations Giza 86 x Pima S6, Giza 77 x Pima S6, Giza 94 x Dandra and Giza 96 x Australy showed significant desirable SCA effect for most characters from water relationship and biochemical characters relative water content $\%$, osmotic pressure, chlorophyll and carotenoids content indicator, the better availability of water in the cell, which increase the photosynthetic rate. Also, the higher level of proline accumulation in the leaves recorded under water deficit conditions suggest that the production of proline is probably a common response of plant under water deficit conditions.

\section{REFERENCES}

Abdel-Kader, M.A.-Esmail, A.M.-EL-Shouny, K.A.-Ahmed M.F. (2015a): Evaluation of the drought stress effects on cotton genotypes by using physiological and morphological traits, Int. J. of Sci. and Res. (IJSR) 4, 1358-1366.

Abdel-Kader, M.A.-Esmail, A.M.-EL-Shouny, K.A.-Ahmed, M.F. (2015b): Screening cotton genotypes for drought tolerance by using non-enzymatic and enzymatic antioxidant systems. Egypt. J. of Plant Breed., 19, 169-184.

Amjid, M.W.-Malik, T.A.-Nawaz Shah, M.K.-Saleem M.A.Sajjad, Y.-Mehmood R. (2016): Inheritance pattern of physiomorphological traits of cotton under drought stress, Science Letters, 4, 51-59.

Ananthi, K.-Vijayaraghavan, H. (2012): Development of drought tolerant index in cotton genotypes based on relative water content and yield, Asian J. Bio. Sci., 7, 138-144.
Anwar, J.-Subhan, G.M.-Hussain, M.-Ahmad, J.-Hussain, M.Munir, M. (2011): Drought tolerance indices and their correlation with yield in exotic wheat genotypes, Pakistan J. Bot., 43, 1527-1530.

Din, J.-Khan, S.U.-Ali I.-Gurmani, A.R. (2011): Physiological and agronomic response of canola varieties to drought stress, The J. Animi. Plant. Sci., 21, 78-83.

Hamayun, M.-Khan, S.A.-Shinwari, Z.K.-Khan, A.L.-Ahmad, N.Lee, I.J. (2010): Effect of polyethylene glycol induced drought stress on physio-hormonal attributes of soybean, Pakistan. J. Bot., 42, 977-986.

Hu, Y.-Zhang, Ya-li.-Xiao-ping, Y.I.-Dong-xia, Z.-Hong-hai, L.Wah Soon Ch.-Wang-feng, Z. (2013): The relative contribution of non-foliar organs of cotton yield and related physiological 
characteristics under water deficit. J. Integrative Agric., 13, 975989.

Iqbal, M.-Khan, M.A.-Jamal, M.-Yar, M.M.-Shakir, S.-Ali A (2011): Study of heritable variation and genetics of yield and yield components in upland cotton, Africain J. Agric. Res., 6, 4099-4103.

Kannan, V.-Srinivasan, G.-Babu, R.-Sivakumar, T. (2017): Effect of biochar, mulch and ppfm spray on leaf relative water content, leaf proline, chlorophyll stabilities index and yield on cotton under moisture stress condition, Int. J. Curr. Microbiol. App. Sci., 6, 604-611.

Kashif, M.-Sarwar, S.-Yasin, M.-Zafar, Y. (2012): Genetic variabilities in different biochemical traits and their relation with yield of cotton cultivar under water stress condition, Pakistan. J. Bot., 44, 515-520.

Kearsey, M.J.-Pooni, H.S. (1996): The Genetical Analysis of Quantitative Traits. Chapman and Hall, London.

Kempthorne, O. (1957): An introduction to genetic statics. Johan wily and sons, Inc. New York, USA, 468-473.

Khan, S.A.-Khan, N.U.-Gul, R.-Bibi, Z.-Khan, I.U.-Gul, S.-Ali, S.-Baloch, M. (2015): Combining abilities studies for yield and fiber traits in upland cotton, The J. Anim. Plant Sci. 25 (3) 698 707.

Kumar, S.-Urbi, M.B.-Rajasekaran, R.-Krishnasamy, T.Narayanan, M.-Boopathi-Sankaran, R. (2012): Association analysis of yield and fiber quality characters in inter-specific population of cotton (Gossypium spp.). J. of Crop Sci. and Biotechnol., 15, 239-243.

Pelc, D.-Steel, C.-Rhythmic, G.H. (1997): Steroidogenesis by the Prothoracic Glands of the Insect Rhodnius prolixusin the Absence of Rhythmic Neuropeptide Input: Implications for the 14 Role of Prothoracicotropic Hormone. General and comparative endocrinology, 10, 358-365.

Pirzad, A.-Shakiba, M.R.-Zehtab-Salmasi S. (2011): Effect of water stress on leaf relative water content, chlorophyll, proline and soluble carbohydrates in Matricaria chamomilla L, J. Medic. Plant Res., 5, 2483-2488.

Rahman, M.-Ullah, I.-Ahsraf, M.-Stewart, J.M.-Zafar Y. (2008): Genotypic variation for drought tolerance in cotton, Agron. Sustain. Dev., 28, 439-447.

Sanchez, A.C.-Subudhi, P.K.-Rosenow, D.T.-Nguyen, H.T. (2002): Mapping QTLs associated with d rought resistance in sorghum (Sorghum bicolor L. Moench). Plant Mol. Biol., 48, 713-726.

Singh, R.K. -Chaudhary, B.D. (1977): Biometrical methods in quantitative genetics analysis, Kalyani publishers, New Delhi, p. 318.

Steel, R.G.-Torrie, J.H.-Dickey, D.A. (1997): Principles and procedures of statistics. A Biometrical Approach 3rd Ed. McGraw Hill book Co. Inc. New York, USA.

Zangi, M.R. (2005): Correlation between drought resistance indices and cotton yield in stress and non-stress conditions, Asian J. of Plant Sci.,4, 106-108. 
